\title{
2,4-Bis(arylethynyl)-9-chloro-5,6,7,8-tetrahydroacridines: synthesis and photophysical properties
}

\author{
Najeh Tka1,2, Mohamed Adnene Hadj Ayed ${ }^{1}$, Mourad Ben Braiek ${ }^{1}$, Mahjoub Jabli \\ Noureddine Chaaben ${ }^{4}$, Kamel Alimi ${ }^{1}$, Stefan Jopp ${ }^{2}$ and Peter Langer ${ }^{* 2,5, \S}$
}

\section{Full Research Paper}

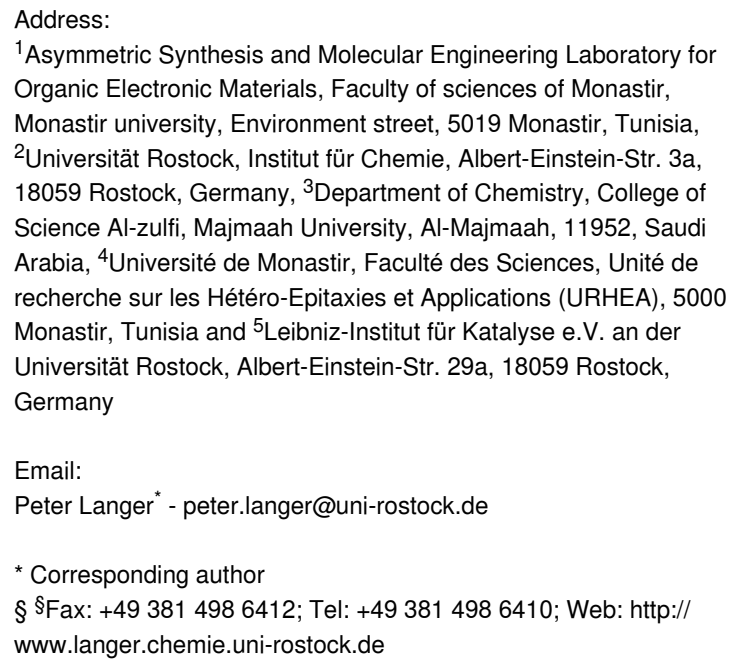

${ }^{1}$ Asymmetric Synthesis and Molecular Engineering Laboratory for Organic Electronic Materials, Faculty of sciences of Monastir, Monastir university, Environment street, 5019 Monastir, Tunisia, ${ }^{2}$ Universität Rostock, Institut für Chemie, Albert-Einstein-Str. 3a, 18059 Rostock, Germany, ${ }^{3}$ Department of Chemistry, College of Science Al-zulfi, Majmaah University, Al-Majmaah, 11952, Saudi Arabia, ${ }^{4}$ Université de Monastir, Faculté des Sciences, Unité de recherche sur les Hétéro-Epitaxies et Applications (URHEA), 5000 Monastir, Tunisia and ${ }^{5}$ Leibniz-Institut für Katalyse e.V. an der Universität Rostock, Albert-Einstein-Str. 29a, 18059 Rostock, Germany

Beilstein J. Org. Chem. 2021, 17, 1629-1640. https://doi.org/10.3762/bjoc.17.115

Received: 26 January 2021

Accepted: 19 May 2021

Published: 16 July 2021

Associate Editor: T. J. J. Müller

(C) 2021 Tka et al.; licensee Beilstein-Institut. License and terms: see end of document.

\begin{abstract}
Acridine derivatives have attracted considerable interest in numerous areas owing to their attractive physical and chemical properties. Herein, starting from readily available anthranilic acid, an efficient synthesis of 2,4-bis(arylethynyl)-9-chloro-5,6,7,8-tetrahydroacridine derivatives was accomplished via a one-pot double Sonogashira cross-coupling method. The UV-visible absorption and emission properties of the synthesized molecules have been examined. Additionally, theoretical studies based on density functional theory (DFT/B3LYP/6-31G(d)) were carried out.
\end{abstract}

\section{Introduction}

The development and design of small $\pi$-conjugated molecules have attracted increasing attention for their inspiring applications in the fields of solar cells [1-3], organic devices [4-8], and as chemosensors $[9,10]$. The acridine core (Figure 1), formed by two benzenes fused to a pyridine ring, is among the most exten- sively studied heterocyclic aromatic compounds. It has first appeared as a side product during the synthesis of anthracene [11] and became an abundant scaffold in medicinal chemistry [12-14]. Acridine derivatives have exhibited a range of biological activities [15-20] and have been particularly explored in 
chemotherapeutic protocols against several types of tumors [21$31]$. In recent years, much attention has been devoted to acridines in materials science due to their attractive photophysical and electrochemical properties [32-35]. They have been investigated in organic electronic devices [36-39] and were reported to be promising candidates for potential use as organic light emitting diodes [40]. Thus, various synthetic methodologies for the preparation of acridine-based molecules have been developed [41-47].

Tetrahydroacridine, containing a partially hydrogenated ring, is another privileged scaffold which showed interesting biological activities [48-54]. As a typical example, 9-amino-1,2,3,4tetrahydroacridine or tacrine was the first drug approved for the treatment of Alzheimer's disease [55-57]. Surprisingly, photophysical properties of tetrahydroacridines have, to the best of our knowledge, not been studied so far. Recently, our research group reported the synthesis of a large variety of acridine derivatives which showed promising fluorescence properties and high quantum yields [58-60]. In continuation of our previous studies and as a part of our interest in discovering new organic materials applications [61-63], we herein report the synthesis of new 2,4-bis(arylethynyl)-9-chloro-5,6,7,8-tetrahydroacridine derivatives. The investigation of their photophysical properties and theoretical DFT studies were achieved aiming to understand the influence of substituents at introduced arylethynyl groups.

\section{Results and Discussion Synthesis}

At the outset of this study, we prepared 2,4-dibromo-9-chloro5,6,7,8-tetrahydroacridine (2) following a two-step approach. We first prepared 3,5-dibromoanthranilic acid (1) by refluxing anthranilic acid with 2.2 equivalents of bromine in acetic acid as previously reported [64]. Subsequently, the $\mathrm{POCl}_{3}$-mediated cyclodehydration of $\mathbf{1}$ and cyclohexanone afforded $\mathbf{2}$ through an adapted reported procedure (Scheme 1) [65].

Tetrahydroacridine 2 represents a novel synthetic building block for Pd catalysis. With this precursor in hand, we intended to expand the $\pi$-conjugation by introducing two arylethynyl groups by Sonogashira reactions [66-69]. For the optimization, we studied the reaction of $\mathbf{2}$ with phenylacetylene (3a) and we obtained the desired product $\mathbf{4 a}$ in up to $72 \%$ as best yield using $0.6 \mathrm{~mol} \%$ of tetrakis(triphenylphosphine)palladium(0) and $1.2 \mathrm{~mol} \%$ of copper iodide (Scheme 2, Table 1).

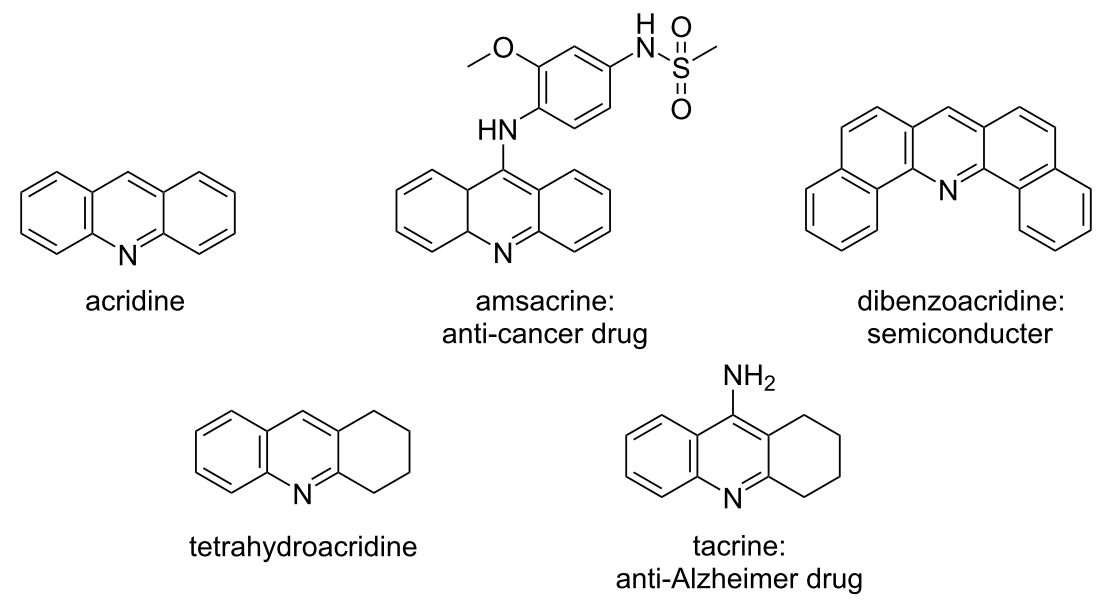

Figure 1: Applications of acridines.<smiles>CC(C(=O)O)(C(=O)O)C(=O)O</smiles> 


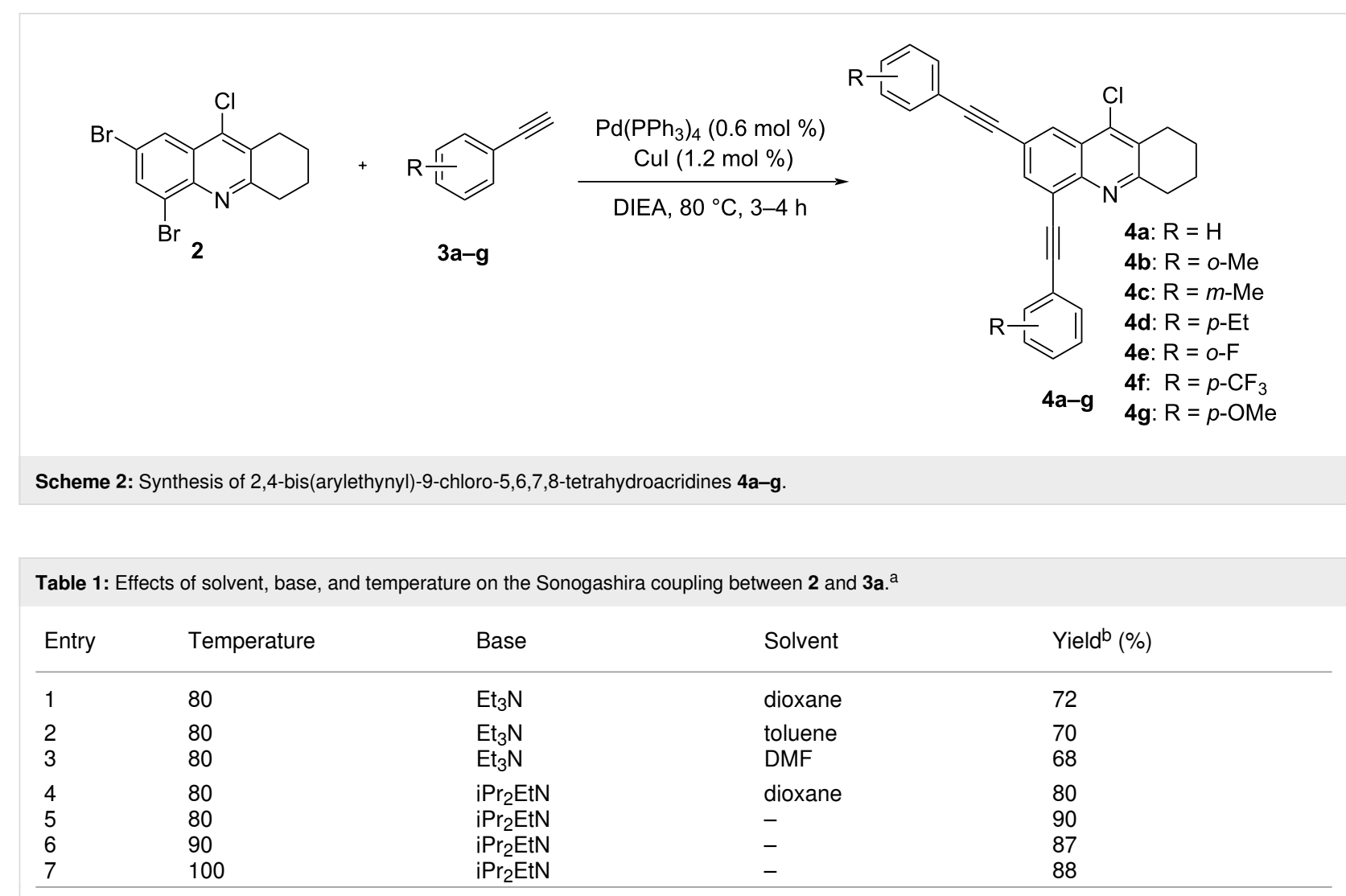

aReagents and conditions: $\mathrm{Pd}\left(\mathrm{PPh}_{3}\right)_{4}(0.6 \mathrm{~mol} \%)$, Cul (1.2 mol \%), solvent $(3 \mathrm{~mL})$, base $(0.5 \mathrm{~mL}), 2(0.5 \mathrm{mmol}), 3 \mathrm{a}(1.1 \mathrm{mmol}), 80{ }^{\circ} \mathrm{C}, 3 \mathrm{~h} .{ }^{\mathrm{b}} / \mathrm{solated}$ yield.

The reaction proceeded chemoselectively at the two carbon-bromine bonds giving 2,4-bis(phenylethynyl)-9-chloro5,6,7,8-tetrahydroacridine (4a). This result was not entirely predictable, as the chlorine atom is located at the more reactive electron-poor pyridine moiety of the heterocyclic core structure. In fact, the chlorine position proved to be quite unreactive and all attempts to isolate 2,4,9-tris(phenylethynyl)-5,6,7,8-tetrahydroacridine failed even after using an excess of phenylacetylene and prolonging the reaction time. In order to study the regioselectivity of the reaction, a series of experiments were carried out with decreasing amounts of phenylacetylene. Although we used one equivalent of phenylacetylene, we were not able to isolate the mono coupling product.

Concerning the catalyst performance, $\mathrm{Pd}\left(\mathrm{PPh}_{3}\right)_{4}$ was found to be a suitable catalyst. In contrast, $\mathrm{PdCl}_{2}\left(\mathrm{PPh}_{3}\right)_{2}$ was slightly less effective and gave lower yields. The replacement of dioxane by toluene or DMF did not lead to any significant improvement of the yields (Table 1, entries 2 and 3). For further improvement of the coupling, we evaluated the effect of the organic base. We found that the use of DIPEA instead of $\mathrm{Et}_{3} \mathrm{~N}$ afforded better yields (Table 1, entry 4). Besides, the use of DIPEA as base and solvent gave a significant improvement of the yield (Table 1, entry 5). Our final effort consisted in evaluating the effect of the temperature. We found that increasing the temperature to 90 or $100{ }^{\circ} \mathrm{C}$ did not lead to any improvement (Table 1, entries 6 and 7).

The best result for the Sonogashira coupling reaction between intermediate $\mathbf{2}$ and phenylacetylene (3a) was obtained using $0.6 \mathrm{~mol} \%$ of $\mathrm{Pd}\left(\mathrm{PPh}_{3}\right)_{4}, 1.2 \mathrm{~mol} \%$ of $\mathrm{CuI}$ in DIPEA at $80{ }^{\circ} \mathrm{C}$ for three hours. With the optimized conditions in hand, we examined the scope of the coupling reaction of 2 with different phenylacetylenes 3b-g. As shown in Table 2, tetrahydroacridine derivatives $\mathbf{4 a}-\mathbf{g}$ were obtained in moderate to good yields. The yields were better for acetylenes containing electron-donating substituents. For example, arylacetylene $\mathbf{3 g}$, bearing a methoxy group, gave the best chemical yield of $93 \%$. However, in case of the electron-attracting trifluoromethyl group (3e), we obtained a somewhat lower, but still good yield of $75 \%$.

\section{Photophysical properties}

As a prominent blue fluorescence was observed for the prepared tetrahydroacridine derivatives, their photophysical properties were investigated. Absorption and emission spectra were measured at room temperature in diluted dichloromethane solu- 
tion and are depicted in Figure 2 and Figure 3. All spectroscopic data, including the maximum of absorption and emission, fluorescence quantum yield, stokes shift, onset of the absorption wavelengths and optical band gap are summarized in
Table 3. Aiming to understand the impact of substituents at arylethynyl groups, spectra of diversely substituted tetrahydroacridines were compared with unsubstituted derivative $\mathbf{4 a}$ taken as reference.

Table 2: Yields of 2,4-bis(arylethynyl)-9-chloro-5,6,7,8-tetrahydroacridine derivatives 4a-g.

\begin{tabular}{|c|c|}
\hline Entry & Arylacetylene \\
\hline
\end{tabular}

1

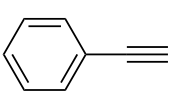

2

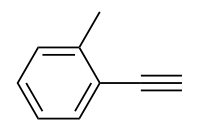

3

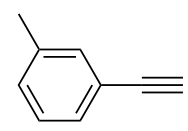

4

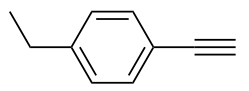<smiles>Clc1c2c(nc3c(C#Cc4ccccc4)cc(C#Cc4ccccc4)cc13)CCCC2</smiles>

4a<smiles>Cc1ccccc1C#Cc1cc(C#Cc2ccccc2C)c2nc3c(c(Cl)c2c1)CCCC3</smiles>

$4 b$<smiles>Cc1cccc(C#Cc2cc(C#Cc3cccc(C)c3)c3nc4c(c(Cl)c3c2)CCCC4)c1</smiles>

$4 c$<smiles>CCc1ccc(C#Cc2cc(C#Cc3ccc(CC)cc3)c3nc4c(c(Cl)c3c2)CCCC4)cc1</smiles>

4d 
Table 2: Yields of 2,4-bis(arylethynyl)-9-chloro-5,6,7,8-tetrahydroacridine derivatives 4a-g. (continued)

5

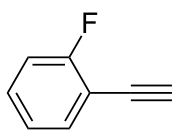

6

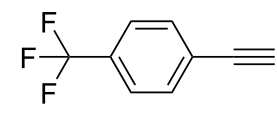

7

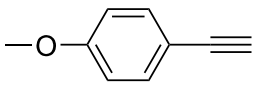<smiles>Fc1ccccc1C#Cc1cc(C#Cc2ccccc2F)c2nc3c(c(Cl)c2c1)CCCC3</smiles>

$4 \mathrm{e}$<smiles>FC(F)(F)c1ccc(C#Cc2cc(C#Cc3ccc(C(F)(F)F)cc3)c3nc4c(c(Cl)c3c2)CCCC4)cc1</smiles>

$4 f$<smiles>COc1ccc(C#Cc2cc(C#Cc3ccc(OC)cc3)c3nc4c(c(Cl)c3c2)CCCC4)cc1</smiles>

$4 g$

asolated yields.

The UV-vis absorption was measured in a spectral rang of $300 \mathrm{~nm}$ to $600 \mathrm{~nm}$. The optical absorption spectra of all compounds spread over the UV range and showed wide absorption bands. These bands are assigned to a $\pi \rightarrow \pi^{*}$ electronic transitions of the quinoline core and its two arylethynyl groups. As shown in Figure 2, the unsubstituted derivative 4a exhibited wide bands with two maxima at 346 and $365 \mathrm{~nm}$. A methyl group at the ortho position have a minor impact and derivative 4b showed similar optical transitions with a slight red shift. While, derivatives $\mathbf{4 e}$ and $\mathbf{4 f}$ bearing an electron-deficient fluoro or trifluoromethyl group show a hyperchromic shift of their bands located between 340 and $380 \mathrm{~nm}$. In case of the electron-donating methoxy substituent $(\mathbf{4 g})$, a bathochromic shift was observed. Besides, a new band appeared at $321 \mathrm{~nm}$ which may be attributed to intermolecular charge transfer between the oxygen lone pair electrons and the quinoline core. The unsubstituted derivative 4a presents an onset of absorption $\left(\lambda_{\text {onset }}\right)$ at $389 \mathrm{~nm}$ and its optical band gap was deduced to be around $3.18 \mathrm{eV}$. Tetrahydroacridines $\mathbf{4 e}$ and $\mathbf{4 f}$ showed approximately the same optical band gaps. However, the optical band gaps of $\mathbf{4 b}$ and $\mathbf{4 g}$ are lower $(3.05 \mathrm{eV}$ and $2.98 \mathrm{eV}$, respectively). 
Table 3: Photophysical properties of $\mathbf{4 a , b}$ and $\mathbf{4 e -}-\mathbf{g}$ in dichloromethane solutions.

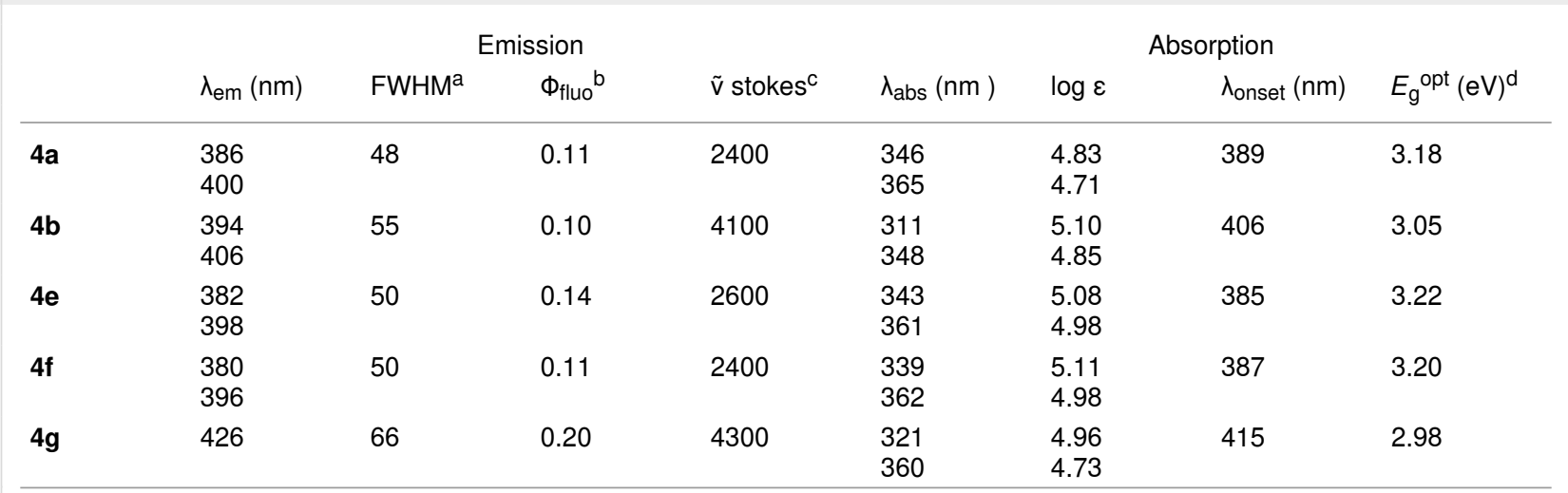

aspectrum full width at half maximum. b Fluorescence standard: quinine bisulfate in $1 \mathrm{~N} \mathrm{H}_{2} \mathrm{SO}_{4}\left(\Phi_{\mathrm{fluo}}=0.54\right)$ [70]. ${ }^{\mathrm{c}} \mathrm{Stokes}$ shift in wavenumber $\left(\mathrm{cm}^{-1}\right)=\left(1 / \lambda_{\mathrm{abs}}{ }^{\max }-1 / \lambda_{\mathrm{em}}{ }^{\max }\right) 10^{7}$. dEstimated from the onset point of the absorption spectra: $E_{\mathrm{g}}{ }^{\text {opt }}=1240 / \lambda_{\mathrm{onset}}[71]$.

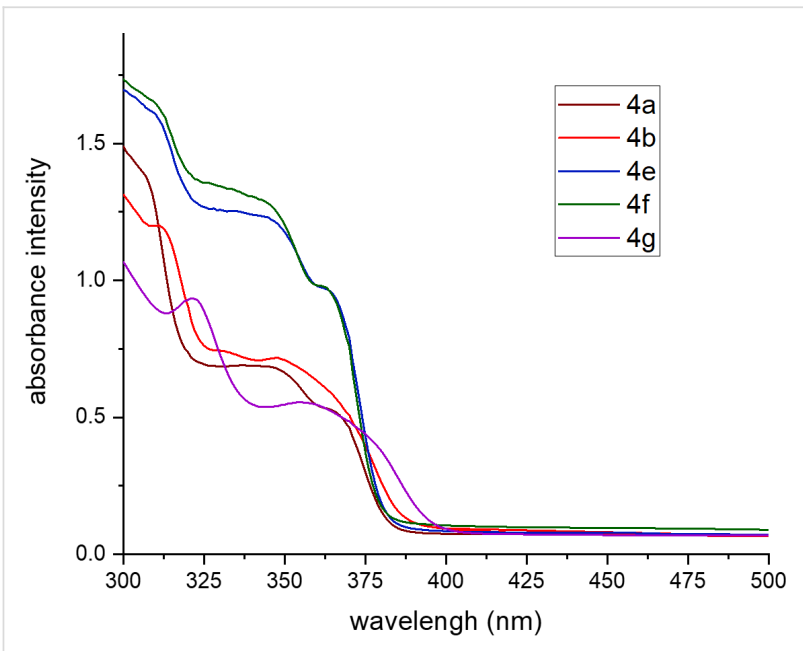

Figure 2: UV-vis absorption spectra of $\mathbf{4 a , b}$ and $\mathbf{4 e - g}$ in diluted dichloromethane solutions at room temperature $\left(c=1 \times 10^{-5} \mathrm{M}\right)$.
Emission spectra of synthesized tetrahydroacridine derivatives were measured in dichloromethane solutions under UV-laser excitation of $325 \mathrm{~nm}$. The emission spectrum of compound $\mathbf{4 a}$ presents a profile with two transitions located at 386 and $400 \mathrm{~nm}$. Methyl-substituted derivative $\mathbf{4 b}$ gave a slight red shift of $10 \mathrm{~nm}$ as compared to $\mathbf{4 a}$. In contrast, fluorine and trifluoromethyl-substituted derivatives $\mathbf{4 e}$ and $\mathbf{4 f}$ show nearly the same emission. However, derivative $\mathbf{4 g}$ containing an electron-donating methoxy substituent exhibits a larger red shift of around $40 \mathrm{~nm}$. Based on the absorption and emission spectra, the prepared tetrahydroacridine derivatives possess stokes shifts (wavenumber) ranging from 2400 to $4300 \mathrm{~cm}^{-1}$. Their fluorescence quantum yields range from 0.1 to 0.2 as measured according to a relative method using quinine sulfate [70]. Tetrahydroacridine derivative $\mathbf{4 g}$ containing an electron-donating methoxy substituent gave the highest fluorescence intensity as shown in Figure 3 and a quantum yield of $20 \%$.
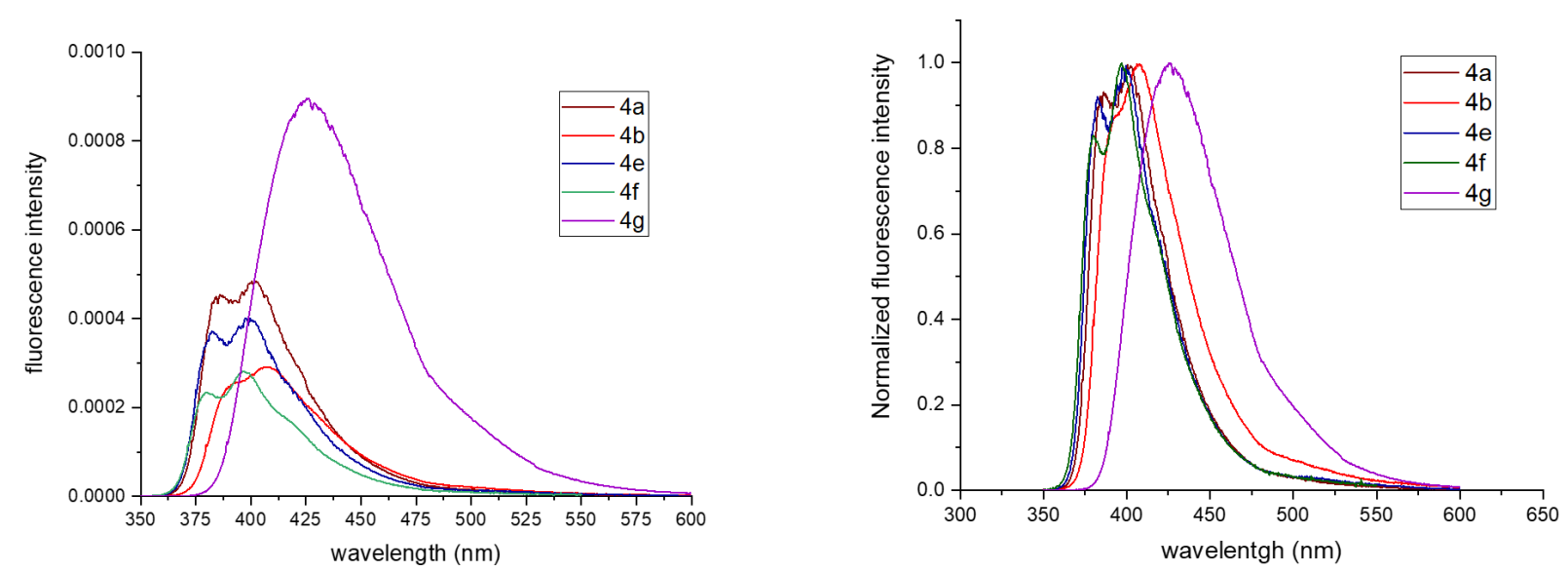

Figure 3: Emission spectra of $\mathbf{4 a , b}$ and $\mathbf{4 e -}-\mathbf{g}$ in diluted dichloromethane solutions at room temperature $\left(c=1 \times 10^{-5} \mathrm{M}\right)$. 


\section{DFT studies}

The arylethynyl substituents showed an impact on the absorption and emission. In order to elucidate these experimental observations, quantum chemical calculations based on density functional theory (DFT) methodology were performed. The estimated visualization of highest occupied and lowest unoccupied molecular orbitals, as well as the molecular electrostatic potential (MEP) of prepared products are given in Table 4.
For phenylethynyl-substituted product $\mathbf{4 a}$, the blue colored surface, located mainly at the cyclohexane ring, visualizes the electron deficiency. While the red region, localized essentially at the nitrogen atom and its closer ethynyl group, show the electron abundance. Due to their low donating effect, the methyl group in product $\mathbf{4 b}$ induce an addition of yellow regions into the external phenyl rings. However, the electron-deficient fluorine atom in derivative $\mathbf{4} \mathbf{e}$ results in a decrease of the electron density of the tetrahydroacridine core and the external phenyl rings.

Table 4: Visualization of HOMO, LUMO orbitals and MEP.
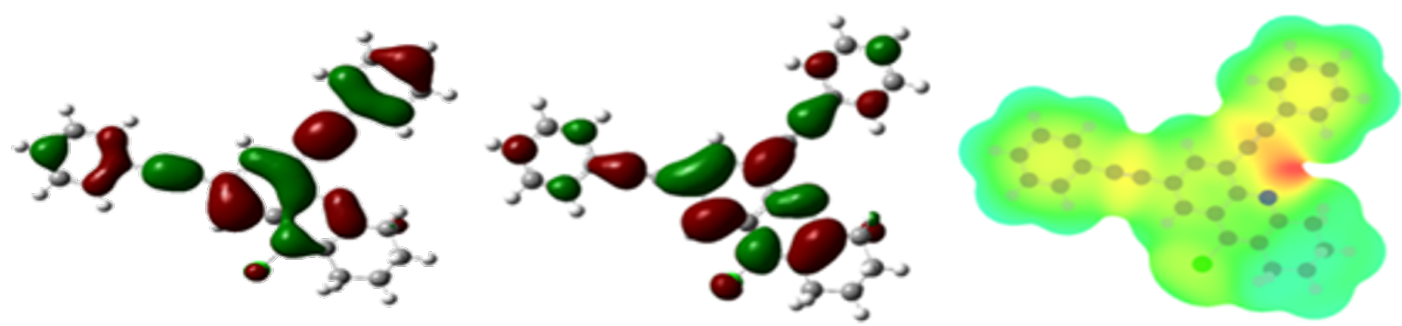

$4 b$


$4 e$
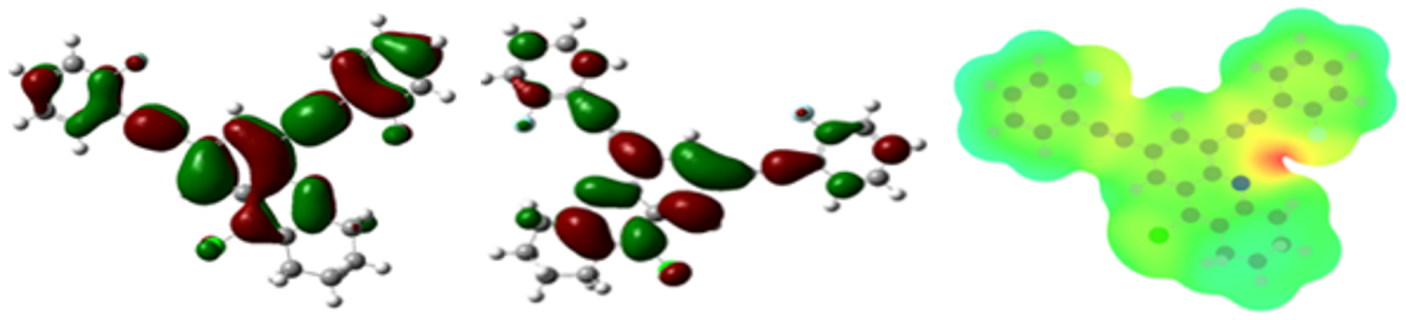

$4 f$
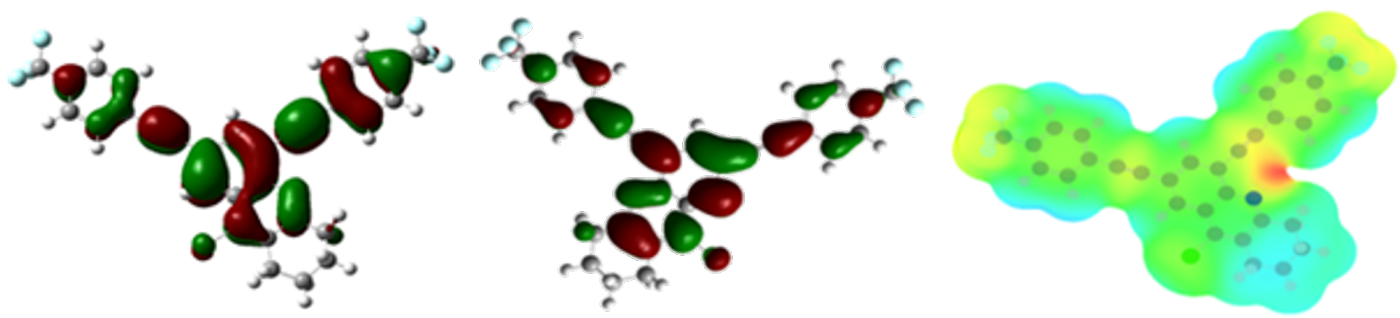

49
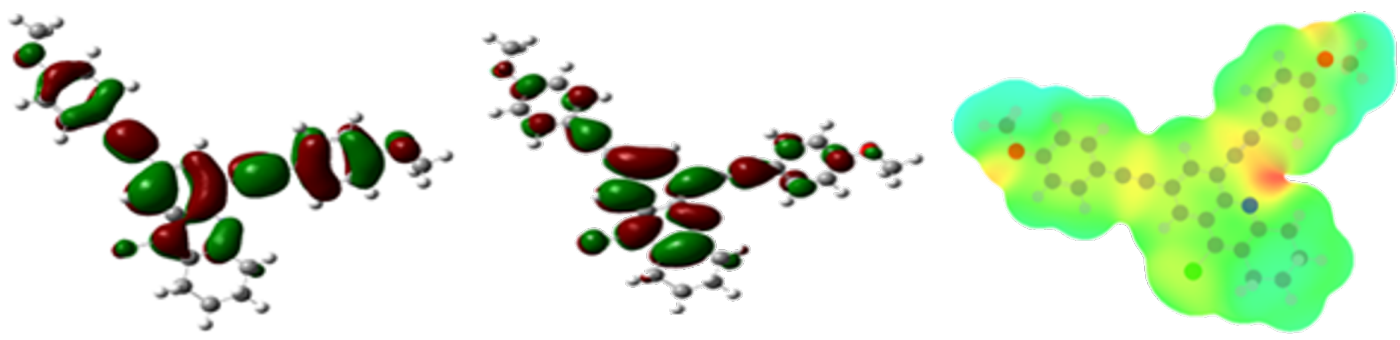
For product $\mathbf{4 f}$, the high electron-deficient effect of the trifluoromethyl groups induces the appearance of blue surfaces around the tetrahydroacridine core, the ethynyl groups and the external phenyl rings, indicating a significant decrease of their electronic densities. However, a yellow-red region is added to the electrostatic map of compound $\mathbf{4 g}$, due to the positive mesomeric effect of the $\pi$-donating methoxy substituent. Accordingly, we conclude that substituents at the introduced arylethynyl groups can communicate electronically with the central tetrahydroacridine core via the ethynyl group. Consequently, they influence the electronic situation of the prepared tetrahydroacridines and are expected to change their structural proprieties. Hence, some structural parameters including gap $\left(E_{\mathrm{g}}\right)$, ionization potential (IP), electron affinity (EA) and dipole moments $(\mu)$ were deduced on the ground state from the optimized chemical structure of obtained molecules (Table 5).

The calculated permanent dipole moments $\mu$ (D) have considerably increased values for $\mathbf{4 f}$ and $\mathbf{4 g}$, which show significant changes in their experimental emission properties. The presence of six fluorine atoms induces a large polarity difference. In fact, derivative $4 \mathbf{f}$ shows the highest dipole moment of 4.276 D as compared to $4 \mathbf{a}(0.698 \mathrm{D})$. As shown in Table 5 , the ionization potential (IP) and electron affinity (EA) of tetrahydroacridines are almost identical. In addition, $E_{\mathrm{HOMO}}$ and $E_{\mathrm{LUMO}}$ do not change notably and the calculated $E_{\mathrm{g}}$ values vary only slightly from 3.26 to $3.55 \mathrm{eV}$. Although, the HOMO energy level of $\mathbf{4 g}$ with $-5.055 \mathrm{eV}$ is higher than $-5.887 \mathrm{eV}$ of $4 \mathbf{e}$, both compounds have close band gap values of $3.36 \mathrm{eV}$ and $3.53 \mathrm{eV}$, respectively.

\section{Conclusion}

In summary, we have reported a facile synthesis of 2,4bis(arylethynyl)-9-chloro-5,6,7,8-tetrahydroacridine derivatives via a double Sonogashira cross-coupling method. The arylethynyl groups expand the $\pi$-conjugation of the tetrahydroacridine core. The substituents located at the aryl group influenced the photophysical properties of the prepared molecules. In particular, the methoxy derivative shows promising fluorescence properties.

\section{Experimental}

\section{Materials and measurements}

All reactions were carried out under an inert argon atmosphere. Anhydrous solvents and chemicals were purchased from SigmaAldrich and used without further purification. All reactions were monitored by thin-layer chromatography (TLC) using commercial silica-gel plate 60 coated with a fluorescence indicator and the visualization was performed by UV $(254 \mathrm{~nm})$. Organic compounds were purified using Merck Silica gel 60 (0.043-0.06 mm). Solvents for work-up and column chromatography were distilled before use.

NMR data were recorded on Bruker ARX 300 instruments in $\mathrm{CDCl}_{3}$ with tetramethylsilane as the internal standard (signals due to the solvent; $\mathrm{CHCl}_{3}$ : $\delta 7.26$ for ${ }^{1} \mathrm{H}$ and $\delta 77.16$ for ${ }^{13} \mathrm{C}$ ). The ${ }^{1} \mathrm{H}$ NMR chemical shifts and coupling constants were determined assuming first-order behavior. Peak characterization of ${ }^{1} \mathrm{H}$ NMR spectra: $\mathrm{s}=$ singlet, $\mathrm{d}=$ doublet, $\mathrm{t}=$ triplet, $\mathrm{q}=$ quartet, $\mathrm{m}=$ multiplet. Chemical shifts were given in ppm $(\delta)$ relative to tetramethylsilane $\left(\mathrm{SiMe}_{4}\right)$. Photophysical studies were carried out in freshly prepared dichloromethane solutions with concentrations of $1 \times 10^{-5} \mathrm{M}$. UV-vis spectra were recorded on a Shimadzu $2401 \mathrm{PC}$ spectrophotometer in quartz cuvettes with a path length of $1 \mathrm{~cm}$. Emission spectra were recorded on a Perkin-Elmer LS50B spectrofluorimeter.

\section{Theoretical calculations}

Theoretical studies were realized in vacuum with Gaussian 09 program [72]. The geometry of the equilibrium conformer at ground state was first found at AM1 level. Then, further optimizations through density functional theory (DFT) approach [73] at the restricted Becke3-Lee-Yang-Parr hybrid functional (B3LYP) with standard basis set 6-31G were carried out.

\section{Experimental procedure and spectroscopic data for 2,4-dibromo-9-chloro-5,6,7,8- tetrahydroacridine (2)}

3,5-Dibromoanthranilic acid (2.92 g, $10 \mathrm{mmol}, 1$ equiv) and cyclohexanone ( $1.07 \mathrm{~mL}, 11 \mathrm{mmol}, 1.1$ equiv) were stirred in an ice bath. Then, $15 \mathrm{~mL}$ of $\mathrm{POCl}_{3}$ was carefully added and the

\begin{tabular}{lllllll}
\multicolumn{2}{l}{ Table 5: Summary of theoretical calculations. } \\
Compound & $E_{\text {HOMO }}$ & E EUMO & IP & EA & $E_{\mathrm{g}}=E_{\text {LUMO }}-E_{\text {HOMO }}(\mathrm{eV})$ & $\mu(\mathrm{D})$ \\
\hline $\mathbf{4 a}$ & -5.499 & -1.992 & 5.5 & 1.99 & 3.5 & 0.698 \\
$\mathbf{4 b}$ & -5.465 & -2.00 & 5.26 & 2 & 3.26 & 0.970 \\
$\mathbf{4 e}$ & -5.553 & -2.033 & 5.55 & 2.0 & 3.55 & 0.657 \\
$\mathbf{4 f}$ & -5.887 & -2.356 & 5.887 & 2.35 & 3.53 & 4.276 \\
$\mathbf{4 g}$ & -5.055 & -1.742 & 5.178 & 1.8 & 3.36 & 1.669 \\
\hline
\end{tabular}

aThe DFT calculations were performed on optimized geometries with a DFT/b3lyp/6-31g(d). 
mixture was heated under reflux for 4 hours. The mixture was cooled to room temperature and concentrated to give a slurry. The residue was diluted with dichloromethane, neutralized with aqueous $\mathrm{NaHCO}_{3}$, and washed with brine. The organic layer was dried over anhydrous $\mathrm{K}_{2} \mathrm{CO}_{3}$ and concentrated to afford a yellow solid. It was recrystallized from acetone to give $\mathbf{2}$ as pale yellow solid (3.24 g, 87\%) [65]. ${ }^{1} \mathrm{H}$ NMR (300 MHz, $\left.\mathrm{CDCl}_{3}\right) \delta$ 1.85-1.95 (m, 4H, $\left.\mathrm{CH}_{2}-\mathrm{CH}_{2}\right), 2.93\left(\mathrm{t},{ }^{3} \mathrm{~J}=6.0 \mathrm{~Hz}, 2 \mathrm{H}, \mathrm{CH}_{2}\right)$, $3.11\left(\mathrm{t},{ }^{3} \mathrm{~J}=6.0 \mathrm{~Hz}, 2 \mathrm{H}, \mathrm{CH}_{2}\right), 8.05(\mathrm{~s}, 1 \mathrm{H}$, aryl-H), $8.21(\mathrm{~s}, 1 \mathrm{H}$, aryl-H); ${ }^{13} \mathrm{C} \mathrm{NMR}\left(75 \mathrm{MHz}, \mathrm{CDCl}_{3}\right) \delta 22.40\left(\mathrm{CH}_{2}\right), 22.42$ $\left(\mathrm{CH}_{2}\right), 27.63\left(\mathrm{CH}_{2}\right), 34.45\left(\mathrm{CH}_{2}\right), 119.73\left(\mathrm{C}_{\mathrm{Ar}}\right), 125.37\left(\mathrm{C}_{\mathrm{Ar}}\right)$, $126.00\left(\mathrm{C}_{\mathrm{Ar}}\right), 127.16\left(\mathrm{C}_{\mathrm{Ar}}\right), 130.78\left(\mathrm{C}_{\mathrm{Ar}}\right), 135.58\left(\mathrm{Cl}-\mathrm{C}_{\mathrm{Ar}}\right)$, $140.36\left(\mathrm{C}_{\mathrm{Ar}}\right), 142.46\left(\mathrm{C}_{\mathrm{Ar}}\right), 161.25\left(\mathrm{~N}=\mathrm{C}_{\mathrm{Ar}}\right)$.

\section{Experimental procedure for the Sonogashira coupling and spectroscopic data for 2,4- bis(arylethynyl)-9-chloro-5,6,7,8-tetrahydro- acridine derivatives $\mathbf{4 a -} \mathbf{g}$}

2,4-Dibromo-9-chloro-5,6,7,8-tetrahydroacridine (2, $372.89 \mathrm{mg}$, 1 mmol, 1 equiv), arylacetylene ( $2.2 \mathrm{mmol}, 2.2$ equiv), $\mathrm{Pd}\left(\mathrm{PPh}_{3}\right)_{4}(6.9 \mathrm{mg}, 0.006 \mathrm{mmol}, 0.6 \mathrm{~mol} \%)$ and $\mathrm{CuI}$ (2.2 mg, $0.012 \mathrm{mmol}, 1.2 \mathrm{~mol} \%$ ) were added to a dried glass pressure tube. The tube was evacuated and backfilled three times with argon, then diisopropylethylamine $(4.0 \mathrm{~mL})$ was added. The tube was sealed with a Teflon cap and heated to $80{ }^{\circ} \mathrm{C}$ for 3-4 hours until completion of the reaction (monitored by TLC). The mixture was then cooled to room temperature and the solvent was removed under reduced pressure. Water $(10 \mathrm{~mL})$ was added and the solution was extracted using $\mathrm{CH}_{2} \mathrm{Cl}_{2}$ $(3 \times 10 \mathrm{~mL})$. The combined organic layers were dried $\left(\mathrm{Na}_{2} \mathrm{SO}_{4}\right)$ and the solvent was evaporated under reduced pressure. The crude product was purified by column chromatography using heptanes/ethyl acetate 9:1 as eluent.

2,4-Bis(phenylethynyl)-9-chloro-5,6,7,8-tetrahydroacridine (4a): colorless solid (375 mg, $0.9 \mathrm{mmol}, 90 \%)$; mp $188-190{ }^{\circ} \mathrm{C}$; ${ }^{1} \mathrm{H}$ NMR $\left(300 \mathrm{MHz}, \mathrm{CDCl}_{3}\right) \delta 1.81-1.92\left(\mathrm{~m}, 4 \mathrm{H}, \mathrm{CH}_{2}-\mathrm{CH}_{2}\right)$, $2.94\left(\mathrm{t},{ }^{3} \mathrm{~J}=6.0 \mathrm{~Hz}, 2 \mathrm{H}, \mathrm{CH}_{2}\right), 3.21\left(\mathrm{t},{ }^{3} \mathrm{~J}=6.0 \mathrm{~Hz}, 2 \mathrm{H}, \mathrm{CH}_{2}\right)$, $7.29-7.35(\mathrm{~m}, 6 \mathrm{H}$, aryl-H), 7.49-7.53 (m, 2H, aryl-H), 7.64-7.68 (m, 2H, aryl-H), $8.01(\mathrm{~s}, 1 \mathrm{H}$, aryl-H), $8.24(\mathrm{~s}, 1 \mathrm{H}$, aryl-H); ${ }^{13} \mathrm{C} \mathrm{NMR}\left(75 \mathrm{MHz}, \mathrm{CDCl}_{3}\right) \delta 22.4\left(\mathrm{CH}_{2}\right), 22.5\left(\mathrm{CH}_{2}\right)$, $30.9\left(\mathrm{CH}_{2}\right), 34.4\left(\mathrm{CH}_{2}\right), 86.5\left(\mathrm{C}_{\mathrm{sp}}\right), 88.5\left(\mathrm{C}_{\mathrm{sp}}\right), 91.1\left(\mathrm{C}_{\mathrm{sp}}\right), 96.2$ $\left(\mathrm{C}_{\mathrm{sp}}\right), 121.3\left(\mathrm{C}_{\mathrm{Ar}}\right), 122.8\left(\mathrm{C}_{\mathrm{Ar}}\right), 123.0\left(\mathrm{C}_{\mathrm{Ar}}\right), 123.3\left(\mathrm{C}_{\mathrm{Ar}}\right), 125.4$ $\left(\mathrm{C}_{\mathrm{Ar}}\right), 127.2\left(\mathrm{C}_{\mathrm{Ar}}\right), 128.3\left(\mathrm{C}_{\mathrm{Ar}}\right), 128.4\left(\mathrm{C}_{\mathrm{Ar}}\right), 128.5\left(\mathrm{C}_{\mathrm{Ar}}\right), 128.6$ $\left(\mathrm{C}_{\mathrm{Ar}}\right), 130.2\left(\mathrm{C}_{\mathrm{Ar}}\right), 131.7\left(\mathrm{C}_{\mathrm{Ar}}\right), 132.0\left(\mathrm{C}_{\mathrm{Ar}}\right), 136.2\left(\mathrm{Cl}-\mathrm{C}_{\mathrm{Ar}}\right)$, $141.5\left(\mathrm{C}_{\mathrm{Ar}}\right), 145.4\left(\mathrm{~N}-\mathrm{C}_{\mathrm{Ar}}\right), 161.1\left(\mathrm{~N}=\mathrm{C}_{\mathrm{Ar}}\right)$; HRMS (ESI): $[\mathrm{M}]^{+}$calcd for $\mathrm{C}_{29} \mathrm{H}_{20} \mathrm{ClN}$, 417.1284; found, 417.1265.

2,4-Bis(o-tolylethynyl)-9-chloro-5,6,7,8-tetrahydroacridine (4b): pale green solid (385 mg, $0.85 \mathrm{mmol}, 85 \%$ ); mp
119-120 ${ }^{\circ} \mathrm{C}$; ${ }^{1} \mathrm{H}$ NMR $\left(300 \mathrm{MHz}, \mathrm{CDCl}_{3}\right) \delta 1.78-1.93(\mathrm{~m}, 4 \mathrm{H}$, $\left.2 \mathrm{CH}_{2}\right), 2.52\left(\mathrm{~s}, 3 \mathrm{H}\right.$, aryl- $\left.\mathrm{CH}_{3}\right), 2.66\left(\mathrm{~s}, 3 \mathrm{H}\right.$, aryl- $\left.\mathrm{CH}_{3}\right), 2.92(\mathrm{t}$, $\left.{ }^{3} J=6.0 \mathrm{~Hz}, 2 \mathrm{H}, \mathrm{CH}_{2}\right), 3.24\left(\mathrm{t},{ }^{3} J=6.0 \mathrm{~Hz}, 2 \mathrm{H}, \mathrm{CH}_{2}\right)$, $7.12-7.25(\mathrm{~m}, 6 \mathrm{H}$, aryl-H), 7.42-7.51 (m, 1H, aryl-H), 7.61-7.66 (m, 1H, aryl-H), $7.95(\mathrm{~s}, 1 \mathrm{H}$, aryl-H), $8.22(\mathrm{~s}, 1 \mathrm{H}$, aryl-H); ${ }^{13} \mathrm{C} \mathrm{NMR}\left(75 \mathrm{MHz}, \mathrm{CDCl}_{3}\right) \delta 20.8\left(\mathrm{CH}_{3}\right), 20.9\left(\mathrm{CH}_{3}\right)$, $22.4\left(\mathrm{CH}_{2}\right), 22.4\left(\mathrm{CH}_{2}\right), 27.5\left(\mathrm{CH}_{2}\right), 34.1\left(\mathrm{CH}_{2}\right), 90.1\left(\mathrm{C}_{\mathrm{sp}}\right)$, $90.2\left(\mathrm{C}_{\mathrm{sp}}\right), 92.3\left(\mathrm{C}_{\mathrm{sp}}\right), 95.8\left(\mathrm{C}_{\mathrm{sp}}\right), 119.7\left(\mathrm{C}_{\mathrm{Ar}}\right), 121.80\left(\mathrm{C}_{\mathrm{Ar}}\right)$, $122.9\left(\mathrm{C}_{\mathrm{Ar}}\right), 123.1\left(\mathrm{C}_{\mathrm{Ar}}\right), 125.5\left(\mathrm{C}_{\mathrm{Ar}}\right), 126.8\left(\mathrm{C}_{\mathrm{Ar}}\right), 128.6\left(\mathrm{C}_{\mathrm{Ar}}\right)$, $128.8\left(\mathrm{C}_{\mathrm{Ar}}\right), 129.4\left(\mathrm{C}_{\mathrm{Ar}}\right), 129.6\left(\mathrm{C}_{\mathrm{Ar}}\right), 130.3\left(\mathrm{C}_{\mathrm{Ar}}\right), 130.4\left(\mathrm{C}_{\mathrm{Ar}}\right)$, $132.1\left(\mathrm{C}_{\mathrm{Ar}}\right), 135.8\left(\mathrm{Cl}-\mathrm{C}_{\mathrm{Ar}}\right), 141.1\left(\mathrm{C}_{\mathrm{Ar}}\right), 145.0\left(\mathrm{~N}-\mathrm{C}_{\mathrm{Ar}}\right), 160.8$ $\left(\mathrm{N}=\mathrm{C}_{\mathrm{Ar}}\right)$; HRMS (ESI): $[\mathrm{M}]^{+}$calcd for $\mathrm{C}_{31} \mathrm{H}_{24} \mathrm{ClN}, 445.1597$; found, 445.1576 .

2,4-Bis(m-tolylethynyl)-9-chloro-5,6,7,8-tetrahydroacridine (4c): pale black solid (364 mg, $0.82 \mathrm{mmol}, 82 \%$ ); $\mathrm{mp}$ 170-172 ${ }^{\circ} \mathrm{C}$; ${ }^{1} \mathrm{H}$ NMR $\left(300 \mathrm{MHz}, \mathrm{CDCl}_{3}\right) \delta 1.80-1.94(\mathrm{~m}, 4 \mathrm{H}$, $\left.2 \mathrm{CH}_{2}\right), 2.31\left(\mathrm{~s}, 3 \mathrm{H}\right.$, aryl- $\left.\mathrm{CH}_{3}\right), 2.33\left(\mathrm{~s}, 3 \mathrm{H}\right.$, aryl- $\left.\mathrm{CH}_{3}\right), 2.92(\mathrm{t}$, $\left.{ }^{3} J=6.0 \mathrm{~Hz}, 2 \mathrm{H}, \mathrm{CH}_{2}\right), 3.21\left(\mathrm{t},{ }^{3} \mathrm{~J}=6.0 \mathrm{~Hz}, 2 \mathrm{H}, \mathrm{CH}_{2}\right)$, 7.05-7.36 (m, 4H, aryl-H), 7.40-7.51 (m, 2H, aryl-H), 7.58-7.64 (m, 2H, aryl-H), $7.91(\mathrm{~s}, 1 \mathrm{H}$, aryl-H), $8.21(\mathrm{~s}, 1 \mathrm{H}$, aryl-H); ${ }^{13} \mathrm{C} \mathrm{NMR}\left(75 \mathrm{MHz}, \mathrm{CDCl}_{3}\right) \delta 21.27\left(\mathrm{CH}_{3}\right), 21.29$ $\left(\mathrm{CH}_{3}\right), 22.41\left(\mathrm{CH}_{2}\right), 22.49\left(\mathrm{CH}_{2}\right), 27.56\left(\mathrm{CH}_{2}\right), 34.36\left(\mathrm{CH}_{2}\right)$, $86.10\left(\mathrm{C}_{\mathrm{sp}}\right), 88.17\left(\mathrm{C}_{\mathrm{sp}}\right), 91.42\left(\mathrm{C}_{\mathrm{sp}}\right), 96.58\left(\mathrm{C}_{\mathrm{sp}}\right), 121.53$ $\left(\mathrm{C}_{\mathrm{Ar}}\right), 122.58\left(\mathrm{C}_{\mathrm{Ar}}\right), 122.96\left(\mathrm{C}_{\mathrm{Ar}}\right), 123.15\left(\mathrm{C}_{\mathrm{Ar}}\right), 125.51\left(\mathrm{C}_{\mathrm{Ar}}\right)$, $127.08\left(\mathrm{C}_{\mathrm{Ar}}\right), 128.19\left(\mathrm{C}_{\mathrm{Ar}}\right), 128.36\left(\mathrm{C}_{\mathrm{Ar}}\right), 129.15\left(\mathrm{C}_{\mathrm{Ar}}\right), 129.62$ $\left(\mathrm{C}_{\mathrm{Ar}}\right), 130.25\left(\mathrm{C}_{\mathrm{Ar}}\right), 132.60\left(\mathrm{C}_{\mathrm{Ar}}\right), 136.37\left(\mathrm{C}_{\mathrm{Ar}}\right), 138.16$ $\left(\mathrm{Cl}-\mathrm{C}_{\mathrm{Ar}}\right), 141.79\left(\mathrm{C}_{\mathrm{Ar}}\right), 145.15\left(\mathrm{~N}-\mathrm{C}_{\mathrm{Ar}}\right), 160.99\left(\mathrm{~N}=\mathrm{C}_{\mathrm{Ar}}\right)$; HRMS (ESI): $[\mathrm{M}]^{+}$calcd for $\mathrm{C}_{31} \mathrm{H}_{24} \mathrm{ClN}$, 445.1597; found, 445.1584 .

\section{2,4-Bis((p-ethylphenyl)ethynyl)-9-chloro-5,6,7,8-tetrahy-} droacridine (4d): pale black solid (392 $\mathrm{mg}, 0.83 \mathrm{mmol}, 83 \%$ ); mp 189-191 ${ }^{\circ} \mathrm{C} ;{ }^{1} \mathrm{H}$ NMR (300 MHz, $\left.\mathrm{CDCl}_{3}\right) \delta 1.19$ (t, 6H, $\left.2 \mathrm{CH}_{3}\right), 1.82-1.93\left(\mathrm{~m}, 4 \mathrm{H}, 2 \mathrm{CH}_{2}\right), 2.54\left(\mathrm{q}, 4 \mathrm{H}, 2 \mathrm{CH}_{2}\right), 2.93(\mathrm{t}$, $\left.{ }^{3} J=6.0 \mathrm{~Hz}, 2 \mathrm{H}, \mathrm{CH}_{2}\right), 3.28\left(\mathrm{t},{ }^{3} J=6.0 \mathrm{~Hz}, 2 \mathrm{H}, \mathrm{CH}_{2}\right)$, 7.11-7.19 (m, 4H, aryl-H), 7.35-7.42 (m, 2H, aryl-H), 7.62-7.69 (m, 2H, aryl-H), $7.96(\mathrm{~s}, 1 \mathrm{H}$, aryl-H), $8.23(\mathrm{~s}, 1 \mathrm{H}$, aryl-H); ${ }^{13} \mathrm{C} \mathrm{NMR}\left(75 \mathrm{MHz}, \mathrm{CDCl}_{3}\right) \delta 15.31\left(\mathrm{CH}_{3}\right), 15.32$ $\left(\mathrm{CH}_{3}\right), 22.26\left(\mathrm{CH}_{2}\right), 22.37\left(\mathrm{CH}_{2}\right), 27.56\left(\mathrm{CH}_{2}\right), 28.89\left(\mathrm{CH}_{2}\right)$, $28.91\left(\mathrm{CH}_{2}\right), 33.99\left(\mathrm{CH}_{2}\right), 85.45\left(\mathrm{C}_{\mathrm{sp}}\right), 87.75\left(\mathrm{C}_{\mathrm{sp}}\right), 91.77$. $\left(\mathrm{C}_{\mathrm{sp}}\right), 97.24\left(\mathrm{C}_{\mathrm{sp}}\right), 119.84\left(\mathrm{C}_{\mathrm{Ar}}\right), 120.39\left(\mathrm{C}_{\mathrm{Ar}}\right), 122.03\left(\mathrm{C}_{\mathrm{Ar}}\right)$, $122.62\left(\mathrm{C}_{\mathrm{Ar}}\right), 125.60\left(\mathrm{C}_{\mathrm{Ar}}\right), 126.73\left(\mathrm{C}_{\mathrm{Ar}}\right), 127.86\left(\mathrm{C}_{\mathrm{Ar}}\right), 128.05$ $\left(\mathrm{C}_{\mathrm{Ar}}\right), 130.41\left(\mathrm{C}_{\mathrm{Ar}}\right), 131.78\left(\mathrm{C}_{\mathrm{Ar}}\right), 132.14\left(\mathrm{C}_{\mathrm{Ar}}\right), 136.72(\mathrm{Cl}-$ $\left.\mathrm{C}_{\mathrm{Ar}}\right), 142.60\left(\mathrm{C}_{\mathrm{Ar}}\right), 144.24\left(\mathrm{C}_{\mathrm{Ar}}\right), 145.08\left(\mathrm{C}_{\mathrm{Ar}}\right), 145.30$ $\left(\mathrm{N}-\mathrm{C}_{\mathrm{Ar}}\right), 160.84\left(\mathrm{~N}=\mathrm{C}_{\mathrm{Ar}}\right)$; HRMS (ESI): $[\mathrm{M}]^{+}$calcd for $\mathrm{C}_{33} \mathrm{H}_{28} \mathrm{ClN}$, 473.1910; found, 473.1924.

2,4-Bis((o-fluorophenyl)ethynyl)-9-chloro-5,6,7,8-tetrahydroacridine (4e): pale red solid (375 $\mathrm{mg}, 0.8 \mathrm{mmol}, 80 \%$ ); $\mathrm{mp}$ 179-181 ${ }^{\circ} \mathrm{C}$; ${ }^{1} \mathrm{H}$ NMR $\left(300 \mathrm{MHz}, \mathrm{CDCl}_{3}\right) \delta 1.81-1.96$ (m, 4H, 
$\left.2 \mathrm{CH}_{2}\right), 2.93\left(\mathrm{t},{ }^{3} \mathrm{~J}=6.0 \mathrm{~Hz}, 2 \mathrm{H}, \mathrm{CH}_{2}\right), 3.25\left(\mathrm{t},{ }^{3} \mathrm{~J}=6.0 \mathrm{~Hz}, 2 \mathrm{H}\right.$, $\left.\mathrm{CH}_{2}\right), 7.06-7.15(\mathrm{~m}, 4 \mathrm{H}$, aryl-H), 7.21-7.31 (m, 2H, aryl-H), 7.45-7.53 (m, 1H, aryl-H), 7.60-7.65 (m, 1H, aryl-H), 8.03 (s, $1 \mathrm{H}$, aryl-H), $8.27\left(\mathrm{~s}, 1 \mathrm{H}\right.$, aryl-H); ${ }^{13} \mathrm{C} \mathrm{NMR}\left(75 \mathrm{MHz}, \mathrm{CDCl}_{3}\right) \delta$ $21.3\left(\mathrm{CH}_{2}\right), 21.4\left(\mathrm{CH}_{2}\right), 26.5\left(\mathrm{CH}_{2}\right), 33.4\left(\mathrm{CH}_{2}\right), 83.5\left(\mathrm{C}_{\mathrm{sp}}\right)$, $88.6\left(\mathrm{C}_{\mathrm{sp}}\right), 90.3 .\left(\mathrm{C}_{\mathrm{sp}}\right), 92.3\left(\mathrm{C}_{\mathrm{sp}}\right), 110.3\left(\mathrm{C}_{\mathrm{Ar}}\right), 110.9\left(\mathrm{C}_{\mathrm{Ar}}\right)$, $114.3\left(\mathrm{C}_{\mathrm{Ar}}\right), 114.8\left(\mathrm{C}_{\mathrm{Ar}}\right), 120.0\left(\mathrm{C}_{\mathrm{Ar}}\right), 121.6\left(\mathrm{C}_{\mathrm{Ar}}\right), 122.9\left(\mathrm{C}_{\mathrm{Ar}}\right)$, $123.0\left(\mathrm{C}_{\mathrm{Ar}}\right), 124.4\left(\mathrm{C}_{\mathrm{Ar}}\right), 126.7\left(\mathrm{C}_{\mathrm{Ar}}\right), 129.2\left(\mathrm{C}_{\mathrm{Ar}}\right), 128.8\left(\mathrm{C}_{\mathrm{Ar}}\right)$, $129.4\left(\mathrm{C}_{\mathrm{Ar}}\right), 129.6\left(\mathrm{C}_{\mathrm{Ar}}\right), 132.9\left(\mathrm{C}_{\mathrm{Ar}}\right), 135.3\left(\mathrm{Cl}-\mathrm{C}_{\mathrm{Ar}}\right), 140.8$ $\left(\mathrm{C}_{\mathrm{Ar}}\right), 144.3\left(\mathrm{~N}-\mathrm{C}_{\mathrm{Ar}}\right), 159.8\left(\mathrm{~F}_{-} \mathrm{C}_{\mathrm{Ar}}\right), 160.04\left(\mathrm{~F}-\mathrm{C}_{\mathrm{Ar}}\right) .163 .8$ $\left(\mathrm{N}=\mathrm{C}_{\mathrm{Ar}}\right)$; HRMS (ESI): $[\mathrm{M}]^{+}$calcd for $\mathrm{C}_{29} \mathrm{H}_{18} \mathrm{ClF}_{2} \mathrm{~N}$, 453.1095; found, 453.1081.

2,4-Bis(( $p$-trifluoromethylphenyl)ethynyl)-9-chloro-5,6,7,8tetrahydroacridine (4f): brown solid $(414 \mathrm{mg}, 0.75 \mathrm{mmol}$, 75\%); mp 170-172 ${ }^{\circ} \mathrm{C} ;{ }^{1} \mathrm{H}$ NMR (300 MHz, $\left.\mathrm{CDCl}_{3}\right) \delta$ 1.81-1.95 (m, 4H, 2CH $), 2.95\left(\mathrm{t},{ }^{3} \mathrm{~J}=6.0 \mathrm{~Hz}, 2 \mathrm{H}, \mathrm{CH}_{2}\right), 3.23$ $\left(\mathrm{t},{ }^{3} \mathrm{~J}=6.0 \mathrm{~Hz}, 2 \mathrm{H}, \mathrm{CH}_{2}\right), 7.51-7.75(\mathrm{~m}, 8 \mathrm{H}$, aryl-H), $8.05(\mathrm{~s}$, $1 \mathrm{H}$, aryl-H), $8.31\left(\mathrm{~s}, 1 \mathrm{H}\right.$, aryl-H); ${ }^{13} \mathrm{C} \mathrm{NMR}\left(75 \mathrm{MHz}, \mathrm{CDCl}_{3}\right) \delta$ $22.3\left(\mathrm{CH}_{2}\right), 22.4\left(\mathrm{CH}_{2}\right), 27.6\left(\mathrm{CH}_{2}\right), 34.5\left(\mathrm{CH}_{2}\right), 86.5\left(\mathrm{C}_{\mathrm{sp}}\right)$, $89.7\left(\mathrm{C}_{\mathrm{sp}}\right), 90.5\left(\mathrm{C}_{\mathrm{sp}}\right), 93.2\left(\mathrm{C}_{\mathrm{sp}}\right), 120.6\left(\mathrm{C}_{\mathrm{Ar}}\right), 122.4\left(\mathrm{C}_{\mathrm{Ar}}\right)$, $125.2\left(\mathrm{~F}_{3} \mathrm{C}-\mathrm{C}_{\mathrm{Ar}}\right), 125.3\left(\mathrm{~F}_{3} \mathrm{C}-\mathrm{C}_{\mathrm{Ar}}\right), 125.4\left(\mathrm{C}_{\mathrm{Ar}}\right), 125.5\left(\mathrm{C}_{\mathrm{Ar}}\right)$, $126.5\left(\mathrm{C}_{\mathrm{Ar}}\right), 127.1\left(\mathrm{C}_{\mathrm{Ar}}\right), 128.2\left(\mathrm{C}_{\mathrm{Ar}}\right), 129.9\left(\mathrm{C}_{\mathrm{Ar}}\right), 130.4\left(\mathrm{C}_{\mathrm{Ar}}\right)$, $130.6\left(\mathrm{C}_{\mathrm{Ar}}\right), 131.9\left(\mathrm{C}_{\mathrm{Ar}}\right), 132.2\left(\mathrm{C}_{\mathrm{Ar}}\right), 136.4\left(\mathrm{Cl}-\mathrm{C}_{\mathrm{Ar}}\right), 141.8$ $\left(\mathrm{C}_{\mathrm{Ar}}\right), 145.5\left(\mathrm{~N}-\mathrm{C}_{\mathrm{Ar}}\right), 161.7\left(\mathrm{~N}=\mathrm{C}_{\mathrm{Ar}}\right)$; HRMS (ESI): $[\mathrm{M}]^{+}$ calcd for $\mathrm{C}_{31} \mathrm{H}_{18} \mathrm{ClF}_{6} \mathrm{~N}$, 553.1032; found, 553.1015.

2,4-Bis((p-methoxyphenyl)ethynyl)-9-chloro-5,6,7,8-tetrahydroacridine (4g): yellow solid (536 mg, $0.93 \mathrm{mmol}, 93 \%)$; mp 125-127 ${ }^{\circ} \mathrm{C}$; NMR $\left(300 \mathrm{MHz}, \mathrm{CDCl}_{3}\right) \delta 1.83-1.92(\mathrm{~m}, 4 \mathrm{H}$, $\left.2 \mathrm{CH}_{2}\right), 2.94\left(\mathrm{t},{ }^{3} \mathrm{~J}=6.0 \mathrm{~Hz}, 2 \mathrm{H}, \mathrm{CH}_{2}\right), 3.33\left(\mathrm{t},{ }^{3} \mathrm{~J}=6.0 \mathrm{~Hz}, 2 \mathrm{H}\right.$, $\mathrm{CH}_{2}$ ), 3.79 (s, 6H, $\left.2 \mathrm{OCH}_{3}\right), 7.75-7.89$ (m, 4H, aryl-H), 7.47 (d, $2 \mathrm{H}$, aryl-H), 8.62 (d, 2H, aryl-H), 7.93 (s, 1H, aryl-H), 8.21 (s, $1 \mathrm{H}$, aryl-H); ${ }^{13} \mathrm{C} \mathrm{NMR}\left(75 \mathrm{MHz}, \mathrm{CDCl}_{3}\right) \delta 22.2\left(\mathrm{CH}_{2}\right), 22.3$ $\left(\mathrm{CH}_{2}\right), 27.5\left(\mathrm{CH}_{2}\right), 33.9\left(\mathrm{CH}_{2}\right), 55.3\left(\mathrm{OCH}_{3}\right), 55.3\left(\mathrm{OCH}_{3}\right)$, $87.2\left(\mathrm{C}_{\mathrm{sp}}\right), 88.7\left(\mathrm{C}_{\mathrm{sp}}\right), 90.2\left(\mathrm{C}_{\mathrm{sp}}\right), 92.2\left(\mathrm{C}_{\mathrm{sp}}\right), 113.9\left(\mathrm{C}_{\mathrm{Ar}}\right), 114.1$ $\left(\mathrm{C}_{\mathrm{Ar}}\right), 114.7\left(\mathrm{C}_{\mathrm{Ar}}\right), 115.3\left(\mathrm{C}_{\mathrm{Ar}}\right), 122.2\left(\mathrm{C}_{\mathrm{Ar}}\right), 122.6\left(\mathrm{C}_{\mathrm{Ar}}\right), 125.6$ $\left(\mathrm{C}_{\mathrm{Ar}}\right), 126.3\left(\mathrm{C}_{\mathrm{Ar}}\right), 130.0\left(\mathrm{C}_{\mathrm{Ar}}\right), 130.4\left(\mathrm{C}_{\mathrm{Ar}}\right), 132.9\left(\mathrm{C}_{\mathrm{Ar}}\right), 133.3$ $\left(\mathrm{C}_{\mathrm{Ar}}\right), 133.7\left(\mathrm{C}_{\mathrm{Ar}}\right), 136.5\left(\mathrm{Cl}-\mathrm{C}_{\mathrm{Ar}}\right), 143.1\left(\mathrm{~N}-\mathrm{C}_{\mathrm{Ar}}\right), 159.9$ $\left(\mathrm{OCH}_{3}-\mathrm{C}_{\mathrm{Ar}}\right), 160.0\left(\mathrm{OCH}_{3}-\mathrm{C}_{\mathrm{Ar}}\right), 160.9\left(\mathrm{~N}=\mathrm{C}_{\mathrm{Ar}}\right)$; HRMS (ESI): $[\mathrm{M}]^{+}$calcd for $\mathrm{C}_{31} \mathrm{H}_{18} \mathrm{ClF}_{6} \mathrm{~N}, 577.1495$; found, 577.1479 .

\section{Supporting Information}

\section{Supporting Information File 1}

Additional experimental data.

[https://www.beilstein-journals.org/bjoc/content/

supplementary/1860-5397-17-115-S1.pdf]

\section{Acknowledgements}

The authors thank Dr. Mourad Chemek for the execution of the DFT study.

\section{Funding}

Financial support from the Deutscher Akademischer Austausch Dienst (DAAD) (scholarship for Najeh TKA) is gratefully acknowledged.

\section{$\mathrm{ORCID}^{\circledR}$ iDs}

Najeh Tka - https://orcid.org/0000-0002-2560-7576 Mohamed Adnene Hadj Ayed - https://orcid.org/0000-0001-8919-2405 Mourad Ben Braiek - https://orcid.org/0000-0001-6742-7445 Kamel Alimi - https://orcid.org/0000-0001-5978-4637 Stefan Jopp - https://orcid.org/0000-0003-2148-7914 Peter Langer - https://orcid.org/0000-0002-7665-8912

\section{References}

1. Hong, T. R.; Shin, J.; Um, H. A.; Lee, T. W.; Cho, M. J.; Kim, G. W.; Kwon, J. H.; Choi, D. H. Dyes Pigm. 2014, 108, 7-14. doi:10.1016/j.dyepig.2014.04.015

2. Reddy, G.; Basak, P.; Jones, L. A.; Della Gaspera, E.; Islavath, N.; Giribabu, L. Sol. Energy 2020, 206, 539-547. doi:10.1016/j.solener.2020.06.040

3. Sun, Z.-Z.; Sun, P.-P.; Feng, S.; Xu, Y.-L.; Liu, J.-F. Synth. Met. 2019, 254, 34-41. doi:10.1016/j.synthmet.2019.05.014

4. Payne, A.-J.; McCahill, J. S. J.; Welch, G. C. Dyes Pigm. 2015, 123, 139-146. doi:10.1016/j.dyepig.2015.07.035

5. Hoang, M. H.; Cho, M. J.; Kim, K. H.; Cho, M. Y.; Joo, J.-s.; Choi, D. H. Thin Solid Films 2009, 518, 501-506. doi:10.1016/j.tsf.2009.07.030

6. Pham, H. T.; Lee, D.-S.; Dao, T. D.; Jeong, H.-D. J. Ind. Eng. Chem. (Amsterdam, Neth.) 2018, 57, 22-27. doi:10.1016/j.jiec.2017.08.003

7. Ma, L.; Yu, Y.; Li, L.; Lei, T.; Jiao, B.; Hou, X.; Wu, Z. Org. Electron. 2018, 57, 123-132. doi:10.1016/j.orgel.2018.02.042

8. Fujita, T.; Haketa, Y.; Maeda, H.; Yamamoto, T. Org. Electron. 2017, 49, 53-63. doi:10.1016/j.orgel.2017.06.028

9. Yan, Z.; Wang, C.; Tang, Y.; Zhu, Y.; Cao, Q.; Yang, T.; Hu, L. Spectrochim. Acta, Part A 2020, 224, 117451. doi:10.1016/j.saa.2019.117451

10. Zhao, Q.; Yuan, H.; Xu, X.; Hu, L.; Gong, P.; Yan, Z. Dyes Pigm. 2019, 165, 217-222. doi:10.1016/j.dyepig.2019.02.030

11. Graebe, C.; Caro, H. Ann. Chem. Pharm. 1871, 158, 265-281. doi:10.1002/jlac.18711580302

12. Kumar, R.; Kaur, M.; Kumari, M. Acta Pol. Pharm. 2012, 69, 3-9. 13. Campbell, N. H.; Parkinson, G. N.; Reszka, A. P.; Neidle, S. J. Am. Chem. Soc. 2008, 130, 6722-6724. doi:10.1021/ja8016973

14. Albert, A. The Acridines. Their Preparation, Physical, Chemical, and Biological Properties and Uses, 2nd ed.; Edward Arnold Ltd.: London, U.K., 1966.

15. Goodell, J. R.; Ougolkov, A. V.; Hiasa, H.; Kaur, H.; Remmel, R.; Billadeau, D. D.; Ferguson, D. M. J. Med. Chem. 2008, 51, 179-182. doi:10.1021/jm701228e

16. Fernández-Calienes Valdés, A. Open Med. Chem. J. 2011, 5, 11-20. doi:10.2174/1874104501105010011 
17. Nowak, K. J. Mol. Struct. 2017, 1146, 562-570. doi:10.1016/j.molstruc.2017.05.042

18. Budiman, M. E.; Bierbach, U.; Alexander, R. W. Biochemistry 2005, 44, 11262-11268. doi:10.1021/bi050745n

19. Sondhi, S. M.; Singh, J.; Rani, R.; Gupta, P. P.; Agrawal, S. K.; Saxena, A. K. Eur. J. Med. Chem. 2010, 45, 555-563. doi:10.1016/j.ejmech.2009.10.042

20. Benoit, A. R.; Schiaffo, C.; Salomon, C. E.; Goodell, J. R.; Hiasa, H.; Ferguson, D. M. Bioorg. Med. Chem. Lett. 2014, 24, 3014-3017. doi:10.1016/j.bmcl.2014.05.037

21. Denny, W. A. Curr. Med. Chem. 2002, 9, 1655-1665. doi:10.2174/0929867023369277

22. Demeunynck, M.; Charmantray, F.; Martelli, A. Curr. Pharm. Des. 2001, 7, 1703-1724. doi:10.2174/1381612013397131

23. Demeunynck, M. Expert Opin. Ther. Pat. 2004, 14, 55e70.

24. Denny, W. A. Med. Chem. Rev.-Online 2004, 1, 257-266. doi: $10.2174 / 1567203043401923$

25. Belmont, P.; Bosson, J.; Godet, T.; Tiano, M. Anti-Cancer Agents Med. Chem. 2007, 7, 139-169. doi:10.2174/187152007780058669

26. Cholewiński, G.; Dzierzbicka, K.; Kołodziejczyk, A. M. Pharmacol. Rep. 2011, 63, 305-336. doi:10.1016/s1734-1140(11)70499-6

27. Dopierała, A.; Wrosz, P.; Mazerski, J. Postepy Hig. Med. Dosw. 2011, 65, 263-269. doi:10.5604/17322693.941521

28. Pérez, S. A.; de Haro, C.; Vicente, C.; Donaire, A.; Zamora, A.; Zajac, J.; Kostrhunova, H.; Brabec, V.; Bautista, D.; Ruiz, J. ACS Chem. Biol. 2017, 12, 1524-1537. doi:10.1021/acschembio.7b00090

29. Galdino-Pitta, M. R.; Pitta, M. G. R.; Lima, M. C. A.; Galdino, L. S.; Pitta, R. I. Mini-Rev. Med. Chem. 2013, 13, 1256-1271. doi:10.2174/1389557511313090002

30. Singh, H.; Singh, H.; Sharma, S.; Singh Bedi, P. M. Heterocycles 2015, 91, 2043-2085. doi:10.3987/rev-15-826

31. Zhang, B.; Li, X.; Li, B.; Gao, C.; Jiang, Y. Expert Opin. Ther. Pat. 2014, 24, 647-664. doi:10.1517/13543776.2014.902052

32. Wiseman, A.; Sims, L. A.; Snead, R.; Gronert, S.; Maclagan, R. G. A. R.; Meot-Ner (Mautner), M. J. Phys. Chem. A 2015, 119, 118-126. doi:10.1021/jp506913r

33. Stępień, M.; Gońka, E.; Żyła, M.; Sprutta, N. Chem. Rev. 2017, 117, 3479-3716. doi:10.1021/acs.chemrev.6b00076

34. Yang, W.; Monteiro, J. H. S. K.; de Bettencourt-Dias, A.; Catalano, V. J.; Chalifoux, W. A. Angew. Chem., Int. Ed. 2016, 55, 10427-10430. doi:10.1002/anie.201604741

35. Zhang, J.; Lakowicz, J. R. J. Phys. Chem. B 2005, 109, 8701-8706. doi:10.1021/jp046016j

36. Magnan, F.; Gabidullin, B.; Brusso, J. L. RSC Adv. 2016, 6, 97420-97429. doi:10.1039/c6ra18897d

37. Yamashita, Y. Sci. Technol. Adv. Mater. 2009, 10, 024313. doi:10.1088/1468-6996/10/2/024313

38. Boudreault, P.-L. T.; Alleyne, B.; Xia, C. Organic electroluminescent materials and devices. U.S. Pat. Appl. US20180013077A1, Jan 11, 2018.

39. Takimiya, K.; Yamamoto, T.; Ebata, H.; Izawa, T. Sci. Technol. Adv. Mater. 2007, 8, 273-276. doi:10.1016/j.stam.2007.02.010

40. Goel, A.; Kumar, V.; Singh, S. P.; Sharma, A.; Prakash, S.; Singh, C.; Anand, R. S. J. Mater. Chem. 2012, 22, 14880. doi:10.1039/c2jm31052j

41. Lian, Y.; Hummel, J. R.; Bergman, R. G.; Ellman, J. A. J. Am. Chem. Soc. 2013, 135, 12548-12551. doi:10.1021/ja406131a
42. Wang, T.-J.; Chen, W.-W.; Li, Y.; Xu, M.-H. Org. Biomol. Chem. 2015, 13, 6580-6586. doi:10.1039/c5ob00755k

43. Tsvelikhovsky, D.; Buchwald, S. L. J. Am. Chem. Soc. 2010, 132, 14048-14051. doi:10.1021/ja107511g

44. Mohammadi-Khanaposhtani, M.; Rezaei, S.; Khalifeh, R.; Imanparast, S.; Faramarzi, M. A.; Bahadorikhalili, S.; Safavi, M.; Bandarian, F.; Nasli Esfahani, E.; Mahdavi, M.; Larijani, B. Bioorg. Chem. 2018, 80, 288-295. doi:10.1016/j.bioorg.2018.06.035

45. Pintori, D. G.; Greaney, M. F. Org. Lett. 2010, 12, 168-171. doi:10.1021/ol902568x

46. Rogness, D. C.; Larock, R. C. J. Org. Chem. 2010, 75, 2289-2295. doi:10.1021/j01000687

47. Huang, X.; Zhang, T. J. Org. Chem. 2010, 75, 506-509. doi:10.1021/j0902311a

48. Olszewska, P.; Mikiciuk-Olasik, E.; Błaszczak-Świątkiewicz, K.; Szymański, J.; Szymański, P. Biomed. Pharmacother. 2014, 68, 959-967. doi:10.1016/j.biopha.2014.10.018

49. Pirrung, M. C.; Chau, J. H.-L.; Chen, J. Chem. Biol. 1995, 2, 621-626. doi:10.1016/1074-5521(95)90127-2

50. Tripathi, R. P.; Verma, S. S.; Pandey, J.; Agarwal, K. C.; Chaturvedi, V.; Manju, Y. K.; Srivastva, A. K.; Gaikwad, A.; Sinha, S. Bioorg. Med. Chem. Lett. 2006, 16, 5144-5147. doi:10.1016/j.bmcl.2006.07.025

51. Czarnecka, K.; Chufarova, N.; Halczuk, K.; Maciejewska, K.; Girek, M.; Skibiński, R.; Jończyk, J.; Bajda, M.; Kabziński, J.; Majsterek, I.; Szymański, P. Eur. J. Med. Chem. 2018, 145, 760-769. doi:10.1016/j.ejmech.2018.01.014

52. Bajda, M.; Jończyk, J.; Malawska, B.; Czarnecka, K.; Girek, M.; Olszewska, P.; Sikora, J.; Mikiciuk-Olasik, E.; Skibiński, R.; Gumieniczek, A.; Szymański, P. Bioorg. Med. Chem. 2015, 23, 5610-5618. doi:10.1016/j.bmc.2015.07.029

53. Szymański, P.; Markowicz, M.; Mikiciuk-Olasik, E. Bioorg. Chem. 2011, 39, 138-142. doi:10.1016/j.bioorg.2011.05.001

54. Nishibori, M.; Oishi, R.; Itoh, Y.; Saeki, K. Jpn. J. Pharmacol. 1991, 55, 539-546. doi:10.1016/s0021-5198(19)39924-x

55. Romero, A.; Cacabelos, R.; Oset-Gasque, M. J.; Samadi, A.; Marco-Contelles, J. Bioorg. Med. Chem. Lett. 2013, 23, 1916-1922. doi:10.1016/j.bmcl.2013.02.017

56. Liu, Z.; Fang, L.; Zhang, H.; Gou, S.; Chen, L. Bioorg. Med. Chem. 2017, 25, 2387-2398. doi:10.1016/j.bmc.2017.02.049

57. Martins, C.; Carreiras, M. C.; León, R.; de los Ríos, C.; Bartolini, M.; Andrisano, V.; Iriepa, I.; Moraleda, I.; Gálvez, E.; García, M.; Egea, J.; Samadi, A.; Chioua, M.; Marco-Contelles, J. Eur. J. Med. Chem. 2011, 46, 6119-6130. doi:10.1016/j.ejmech.2011.09.038

58. Flader, A.; Ohlendorf, L.; Ehlers, P.; Ammon, E.; Villinger, A.; Langer, P. Adv. Synth. Catal. 2019, 361, 2981-2991. doi:10.1002/adsc.201900034

59. Janke, S.; Boldt, S.; Ghazargan, K.; Ehlers, P.; Villinger, A.; Langer, P. Eur. J. Org. Chem. 2019, 6177-6197. doi:10.1002/ejoc.201900913

60. Janke, J.; Villinger, A.; Ehlers, P.; Langer, P. Synlett 2019, 30 , 817-820. doi:10.1055/s-0037-1612256

61. Tka, N.; Jabli, M.; Saleh, T. A.; Salman, G. A. J. Mol. Liq. 2018, 250 , 423-432. doi:10.1016/j.molliq.2017.12.026

62. Jabli, M.; Tka, N.; Ramzi, K.; Saleh, T. A. J. Mol. Liq. 2018, 249, 1138-1144. doi:10.1016/j.molliq.2017.11.126

63. Jabli, M.; Tka, N.; Salman, G. A.; Elaissi, A.; Sebeia, N.; Hamdaoui, M. J. Mol. Liq. 2017, 242, 272-283. doi:10.1016/j.molliq.2017.07.018

64. Modh, R. P.; De Clercq, E.; Pannecouque, C.; Chikhalia, K. H. J. Enzyme Inhib. Med. Chem. 2014, 29, 100-108. doi:10.3109/14756366.2012.755622 
65. Keri, R. S.; Quintanova, C.; Marques, S. M.; Esteves, A. R.; Cardoso, S. M.; Santos, M. A. Bioorg. Med. Chem. 2013, 21, 4559-4569. doi:10.1016/j.bmc.2013.05.028

66. Dehbanipour, Z.; Moghadam, M.; Tangestaninejad, S.; Mirkhani, V.; Mohammadpoor-Baltork, I. J. Organomet. Chem. 2017, 853, 5-12. doi:10.1016/j.jorganchem.2017.10.006

67. Gogoi, R.; Saikia, R.; Borah, G. J. Organomet. Chem. 2019, 897, 80-88. doi:10.1016/j.jorganchem.2019.06.015

68. Modak, A.; Mondal, J.; Bhaumik, A. Green Chem. 2012, 14, 2840. doi:10.1039/c2gc35820d

69. Gogoi, A.; Dewan, A.; Borah, G.; Bora, U. New J. Chem. 2015, 39, 3341-3344. doi:10.1039/c4nj01822b

70. Melhuish, W. H. J. Phys. Chem. 1961, 65, 229-235. doi:10.1021/j100820a009

71. Qin, Y.; Gu, H.; Liu, S.; Dai, W.; Luo, X. Synth. Met. 2018, 245, 42-50. doi:10.1016/j.synthmet.2018.08.008

72. Gaussian 09, Revision B.01; Gaussian, Inc.: Wallingford, CT, USA, 2009.

73. Koch, W.; Holthausen, M. C. A. Chemist's Guide to Density Functional Theory; Wiley-VCH: Weinheim, Germany, 2000. doi:10.1002/3527600043

\section{License and Terms}

This is an Open Access article under the terms of the Creative Commons Attribution License (https://creativecommons.org/licenses/by/4.0). Please note that the reuse, redistribution and reproduction in particular requires that the author(s) and source are credited and that individual graphics may be subject to special legal provisions.

The license is subject to the Beilstein Journal of Organic Chemistry terms and conditions: (https://www.beilstein-journals.org/bjoc/terms)

The definitive version of this article is the electronic one which can be found at: https://doi.org/10.3762/bjoc.17.115 